\title{
The Impacts of Brand image, Brand love, and Brand Trust on Brand Loyalty: Case Study on Coffee Drinks
}

\author{
Ali Wardhana ${ }^{1, *} \&$ Yulia $^{2}$ \\ ${ }^{1}$ Universitas Bunda Mulia, Jakarta, Indonesia \\ ${ }^{2}$ Universitas Bunda Mulia, Jakarta, Indonesia \\ *Corresponding Author. Email: awardhana@bundamulia.ac.id
}

\begin{abstract}
This paper aims to investigate the effect of brand image, brand love, and brand trust to brand loyalty in coffee drinks, especially in the Kopi Kenangan's brand and not only investigate the impact but also compare brand love, and brand trust for seeking which variable that has a bigger impact. The total data collected is 100 samples with the majority is female (62\% respondents). The data analyzed with PLS SEM and give a result that only brand image does not have an impact on brand loyalty. From the data analyzed, this research supports the prior research that brand love and brand trust have a positive impact to brand loyalty. This research also found for brand Kopi Kenangan brand love have a bigger impact than brand trust.
\end{abstract}

Keywords: Brand image, Brand Love, Brand trust, Brand loyalty.

\section{INTRODUCTION}

The pandemic covid19 has forced governments around the world to lockdown their society as a preventive action. As a result of that action many countries, including Indonesia get a new problem, economic crisis. In a publication published by the Ministry of Finance, it is stated that there are 180 countries in the world, $92 \%$ of which are certain to experience negative growth in 2020 (Ministry of Finance, 2020). In contrast with the negative growth situation, the food and beverage industry still can grow 3.94\% (Ministry of Industry, 2020) and it can show how big the opportunity in the food and beverage industry in Indonesia and will attract foreign investors to invest in Indonesia's food and beverage industry. One of the big investment in the middle of a pandemic covid19 is seed funding series B for Kopi Kenangan led by
Sequoia Capital. The start-up coffee chain, which was founded in 2017, is success received funding 3 times, namely seed funding in 2018 by Alpha JWC, series A funding worth US \$ 20 million in June 2019 by Sequoia Capital, and series B funding worth US \$ 109 million by Sequoia Capital in 2020 (CNBC, 2020). Phenomena seed funding for start-up coffee chain raises 2 questions, why coffee chain start-up that has 3 years get big funding and how does Kopi kenangan keep up their performance. That two questions can answer with the brand concept because through brand consumer not only able to identify a product and differentiate their product from other products (Ahmad et al., 2016) but also brand able to become a vehicle to meet the challenges of building long-term relationships with customers (Pedeliento et al., 2016). To look at this relationship, the researcher can use the lovemark theory 
which can show the relationship between brand and consumer loyalty (Song, et al., 2019). In prior research, lovemark has affected significantly to loyalty to repurchase intention and positive word of mouth which is a manifestation of loyalty (Wardhana, 2020) Lovemark stands on 2 main pillars, namely brand love and brand respect where one of brand respect's element is brand trust. Brand trust is a rational variable and brand love is an emotional variable (Huang, 2017) where these two variables in earlier research have been shown to influence 2 dimensions of brand loyalty, namely the dimensions of attitude and behavior (Hwang and Kandampully, 2012). Both brand trust and brand love can be affected by brand image (Song, et al., 2019; Al-Haddad, 2019) and at the same time brand image also have a positive impact to brand loyalty (Anwar et al., 2011; Al-Haddad, 2015). Based on the explanation that brand image has a function to make an impact significantly on brand loyalty and simultaneously affect on brand love, and brand trust, then this studies will look at the impact of brand image, brand love, and brand trust to brand loyalty on coffee drinks, especially in kopi kenangan's brand.

\subsection{Brand Image}

Brand image refers to a series of an impression generated by the consumer through observation and the consumption in which the impression tends to convert brand image as a decision maker's factor (AlHaddad 2015) and because of that brand image has an essential role in building a brand (Al-Haddad 2019). In prior research, brand trust has a significant positive impact on brand image (Anwar et al. 2011, AlHaddad 2015, Song et al. 2019). Besides that, the brand image also has an influence positive and significant with brand love..

$\mathrm{H}_{1}$ : Brand trust has an impact on brand love.
$\mathrm{H}_{2}$ : Brand image has an impact on brand love.

In prior studies brand image also give an impact to brand loyalty (Anwar et al., 2011; Al-Haddad, 2015). Other research also found, with mediated by consumer satisfaction, brand image can still affect brand loyalty significantly (Song, et al., 2019).

$\mathrm{H}_{3}$ : Brand image has an impact on brand loyalty.

\subsection{Brand Love}

Brand love is believed can run the role of a bridge between product and consumer. Brand love to bring an emotional attitude towards brands is a key factor influencing the brand selection and consumer brand loyalty (Song, et al., 2019). By looking at the relationship between brands and consumer loyalty, brand love can be considered as construction that indicates the level of relationship between brands and consumers and the quality of brand relationships (Pandir and Yasin, 2017). In other research, brand love refers to the longterm relationship of a brand with consumers and brand love also has an impact on creating strong satisfaction when consumer satisfaction with a brand or product turns into love (Unal and Aydin, 2013). In the research by Pandir and Yasin, (2017) it was also revealed that brand love is derived from the area of interpersonal relationships, but this does not mean that everything that comes from the area of interpersonal relationships can be categorized into brand love.

$\mathrm{H}_{4}$ : Brand Love has an impact on brand loyalty.

\subsection{Brand Trust}

Brand trust is a sense of security that consumers have in their interactions with 
brands, where the sense of security is based on the perception about the reliability of a brand and how a brand can be responsible for the welfare and interests of consumers (Hernandez-Fernandez \& Lewi. 2019). The brand trust concept can become a key factor to build a long-term relationship between consumers and the companies. That relationship can occur when consumers trust a company's product, and then it is very likely that some forms of positive consumer behavior intention for the company will arise (Yang \& Liu, 2018).

H5: Brand Trust has an impact on brand loyalty.

\subsection{Brand Loyalty}

Brand loyalty has used by many companies to keep up their market share because the form of brand loyalty is to repurchase product over a long period time, make a positive wom for a particular brand (Can dan Edil, 2018), and willingness to pay at a higher price (Giovanis and Athanasopoulou, 2018). In other words, brand loyalty has an important role to make a product sustainable in market and become one of the keys to the success of a brand in the market. Definition of brand loyalty is degree of loyalty consumers to a particular brand without look competing for brand marketing activity (Giovanis and Athanasopoulou, 2018).

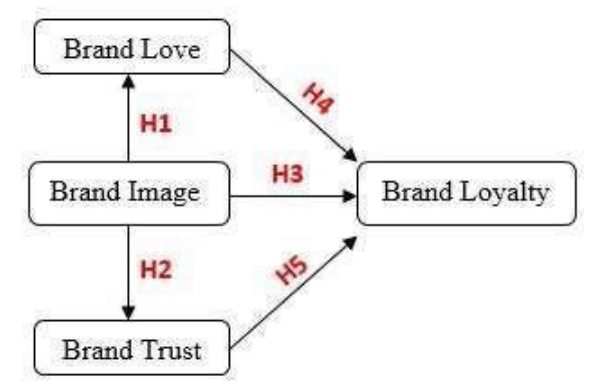

Figure 1. Hypothesis Framework

\section{RESEARCH METHODS}

Research's population is consumer of Kopi Kenangan with a target sample 200 persons. This sample refer to suggests from Sekaran and Bougie (2016) that say the size of sample more than 30 and less than 500 .

This research uses quantitative methods with an instrument research questionnaire distributed online. The questionnaire uses likert scale and processed using PLS-SEM.

\section{DATA ANALYSIS AND RESULTS}

After collecting data, this research gets 100 samples with demographic characteristics of respondent categorized by sex, age, and jobs. Demographics by sex give result $62 \%$ female and $28 \%$ male. In the term of age group, majority of respondents is below 30 with details $48 \%$ between $17-22$ years old and $24 \%$ between $23-28$ years old. The last demographic by jobs dominated by 2 jobs, $46 \%$ students and $44 \%$ employees. After categorizes the data, the next step for measurement model in validity test and this research two test, namely discriminant and convergent validity. The result for convergent validity, all constructs get score above 0,7 after eliminated 1 variable. For discriminant validity use Fornell-Locker's criteria and the result summarized by tabel 1 . Result of two type validity indicates the measurement model has good validity.

Table 1 Discrimant Validity

\begin{tabular}{lllll}
\hline & $\begin{array}{l}\text { Brand } \\
\text { Image }\end{array}$ & $\begin{array}{l}\text { Brand } \\
\text { Love }\end{array}$ & $\begin{array}{l}\text { Brand } \\
\text { Loyalty }\end{array}$ & $\begin{array}{l}\text { Brand } \\
\text { Trust }\end{array}$ \\
\hline $\begin{array}{l}\text { Brand } \\
\text { Image }\end{array}$ & 0.771 & & & \\
$\begin{array}{l}\text { Brand } \\
\text { Love }\end{array}$ & 0.633 & 0.835 & & \\
$\begin{array}{l}\text { Brand } \\
\text { Loyalty }\end{array}$ & 0.483 & 0.679 & 0.814 & \\
$\begin{array}{l}\text { Brand } \\
\text { Trust }\end{array}$ & 0.694 & 0.722 & 0.667 & 0.821 \\
\hline
\end{tabular}

The next measurement of the model is the reliability test that uses 2 ways, namely by looking at the Cronbach's Alpha value and 
composite reliability. A model is said to be reliable if the item being measured can be accepted if the chonbach's alpha value is in the range 0.6 to 0.7 (Sekaran and Bougie, 2016) and composite reliability where the test result value is expected to be above 0.7 (Ghozali and Latan, 2015). The result of reliability test summarized by tabel 2 and from the assessment, the model used in this research has adequate reliability.

Table 2 Reliability testing results

\begin{tabular}{lll}
\hline & $\begin{array}{l}\text { Cronbach's } \\
\text { alpha }\end{array}$ & $\begin{array}{l}\text { Composite } \\
\text { Reliability }\end{array}$ \\
\hline $\begin{array}{l}\text { Brand } \\
\text { Image }\end{array}$ & 0.827 & 0.879 \\
$\begin{array}{l}\text { Brand } \\
\text { Love } \\
\text { Brand } \\
\text { Loyalty } \\
\text { Brand } \\
\text { Trust }\end{array}$ & 0.855 & 0.902 \\
\hline
\end{tabular}

Regarding the hypothesis test by PLSSEM, only one hypothesis is not supported because the $p$-value is above 0.05 . The results of the hypothesis test are summarized in Table 3.

Table 3 Hypothesis testing results

\begin{tabular}{ll}
\hline \multicolumn{1}{c}{ Hypothesis } & \multicolumn{1}{c}{ Results } \\
\hline Brand image $->$ brand love & Supported \\
Brand image $->$ brand love & Supported \\
Brand image $->$ brand loyalty & Not Supported \\
Brand Love $->$ brand Loyalty & Supported \\
Brand Trust $->$ brand Loyalty & Supported \\
\hline
\end{tabular}

\section{DISCUSSION AND CONCLUSION}

This research shows that brand loyalty in coffee drinks, especially in the Kopi Kenangan's brand, can well be built by brand love and brand trust. However, if look more specific, this studies found that brand love more impactfull than brand trust. The bigger impact of brand love is expected to become something positive for start-up in the coffee industry, especially the Kopi Kenangan brand because brand love is able to build long-term relationships between brands and consumers. The bigger impact of brand love from brand trust is presumably related to the name of the Kopi Kenangan brand which is full of emotionality and also the product names of Kopi Kenangan such as the most beautiful ex and the ex married. In addition to the use of the emotional side, it should also be assumed that the majority of respondents are young, namely the age range of 17-22 years, as many as $48 \%$ of the total respondents feel that they are following the use of the emotional side in marketing strategies. The majority of respondents at a young age are also suspected of being the cause of brand image that does not affect brand loyalty, considering that young people tend to choose based on feelings of liking rather than brand image. Another factor that causes a brand image that does not affect brand loyalty is the object of research. In AlHaddad's (2015) research using sportswear research objects and Anwar et al.'s (2011) research using well-known product brand research objects where the two research objects are closely related to brand image In future research, it is necessary to look at the impact of exposure to technology and social media in building brand love among young people who are so close to technology. Besides, future research can examine and compare several similar coffee brands to confirm similiar impact from another element of lovemark.

\section{REFERENCES}

Ahmad, Z., Jun, M., Khan, I., Abdullah, M., \& Ghauri, T. A. 2016. Examining mediating role of customer loyalty for influence of brand related attributes on customer repurchase intention. Journal of Northeast Agricultural University (English Edition) 23(2): 89-96.

Al-Haddad, A. 2015. Perceived quality, brand image and brand trust as determinants of brand loyalty. Journal of Research in Business and Management 3(4): 01-08. 
Al-Haddad, A. 2019. Social Identification, Brand Image and Customer Satisfaction as Determinants of Brand Love. In Creative Business and Social Innovations for a Sustainable Future; Proceeding of the 1st American University in the Emirates International Research Conference. Dubai $15-16^{\text {th }}$ November 2017. Berlin: Springer.

Anwar, A., Gulzar, A., Sohail, F. B., \& Akram, S. N. 2011. Impact of brand image, trust and af- fect on consumer brand extension attitude: the mediating role of brand loyalty. International Journal of Economics and Management Sciences 1(5): 7379.

Can, Y., \& Erdil, O. 2018. Determining Anteced- ent of Re-Purchase Intention: The Role of Perceived Value and Consumer's Interest Factor. International Business Research 11(4): 17-31.

CNBC. 2020. Manis! Kopi Kenangan Diguyur 1,64T di tengah Corona.Retrived from: https://www.cnbcindonesia.com/tech/ 20200512161840-37-157959/manis-kopikenangan- diguyur-rp-164-t-di-tengah-corona.

Ghozali, I., \& Latan, H. 2015. Partial Least Squares, Konsep, Teknik dan aplikasi menggunakan program SmartPLS 3.0. emarang: Badan Penerbit -Undip.

Giovanis, A. N., \& Athanasopoulou, P. 2018. Consumer-brand relationships and brand loyalty in technology-mediated services. Journal of Retailing and Consumer Services. 40 (January): 287-294.

Hernandez-Fernandez, A., \& Lewis, M. C. 2019. Brand authenticity leads to perceived value and brand trust. European Journal of Management and Business Economics. 28(3): 222-238.

Huang, C. C. 2017. The impacts of brand experiences on brand loyalty: mediators of brand love and trust. Management Decision.55(5):915-934.

Hwang, J., \& Kandampully, J. 2012. The role of emotional aspects in younger consumer-brand relationships. Journal of Product \& Brand Management.21(2):98-108.

Kementrian keuangan. 2020. Ancaman Resesi Tak Dapat Dihindari, 92\% Negara di Dunia Mengalaminya. Retrieved from: https://www.kemenkeu.go.id/publikasi/berita /ancaman-resesi-tak-dapat-dihindari-92-negara-didunia-mengalaminya/.

Pandir, B., \& Yasin, B. 2017. Brand love and customer engagement's role over brand loyalty. Journal of Management Marketing and Logistics 4(4): 359-365.

Pedeliento, G., Andreini, D., Bergamaschi, M., \& Salo, J. 2016. Brand and product attachment in an industrial context: The effects on brand loyalty. Industrial Marketing Management 53:194-206.

Sekaran,U. \& Bougie, R.J. 2016. Research Methods for Business: A Skill Building Approach. United Kingdom: John Wiley and Sons Ltd.

Song, H., Wang, J., \& Han, H. 2019. Effect of image, satisfaction, trust, love, and respect on loyalty formation for name-brand coffee shops. International Journal of Hospitality Management 79(May): 50-59.

Unal, Sevtap, \&Hatice Aydin.2013. An Investigation on the Evaluation of the Factors Affecting Brand Love. Procedia: Social Behavioral Siences. Vol 92:76-85.

Wardhana, A. 2020. Pengaruh Brand Respect Terhadap Lovemark Pada Produk Smartphone Asal China. CAPITAL: Jurnal Ekonomi dan Manajemen, 4(1): 43-53.

Yang, Y. C., \& Liu, S. W. (2018). Links between switching costs, brand trust, and customer loyalty in mobile phone services. Interna- tional Journal of Organizational Innovation (Online) 10(4): 315326. 